\section{TINJAUAN YURIDIS TERHADAP KAWASAN TANPA ROKOK DI KOTA MANADO ${ }^{1}$ \\ Oleh : Dion Samuel John ${ }^{2}$ \\ Theodorus H. W. Lumunon ${ }^{3}$ \\ Dientje Rumimpunu ${ }^{4}$}

\begin{abstract}
ABSTRAK
Pernyataan bahwa rokok berdampak buruk bagi kesehatan juga sudah jelas disebutkan pada Konsideran huruf a dan b Peraturan Bersama Menteri Kesehatan dan Menteri Dalam Negeri No. 188 Tahun
\end{abstract} 2011/MENKES/PB/I/No. 7 Tahun 2011 yang menyatakan bahwa asap rokok terbukti dapat membahayakan kesehatan individu, masyarakat dan lingkungan sehingga perlu dilakukan tindakan perlindungan terhadap paparan asap rokok. Bahwa dalam rangka melindungi individu, masyarakat dan lingkungan terhadap paparan asap rokok, pemerintah daerah perlu menetapkan kawasan tanpa rokok. Di Provinsi Sulawesi Utara, khususnya di Kota Manado, pemerintah daerah telah menerapkan kebijakan hukum tentang kawasan tanpa rokok melalui Peraturan Daerah Kota Manado No. 5 Tahun 2017 tentang Kawasan Tanpa Rokok dan Peraturan Gubernur Sulut No. 31 Tahun 2017 tentang Kawasan Tanpa Asap Rokok. Artikel ini bertujuan untuk menjelaskan pengaturan hukum terhadap kawasan tanpa rokok menurut peraturan perundang - undangan serta bagaimana penerapan kebijakan hukum tentang kawasan tanpa rokok di Kota Manado. Jenis penelitian yang digunakan oleh penulis adalah penelitian yuridis normatif, yaitu dengan melakukan pendekatan kepada peraturan perundang - undangan dan konsep - konsep. Hasil penelitian menunjukkan. Pengaturan terhadap kawasan tanpa rokok dapat didapati pada Pasal 115 Undang Undang No. 36 Tahun 2009 tentang Kesehatan, Peraturan Bersama Menteri Kesehatan dan Menteri Dalam Negeri Nomor 188/MENKES/PB/I/2011 Nomor 7 Tahun 2011 tentang Pedoman Pelaksanaan Kawasan Tanpa Rokok, serta Peraturan Pemerintah No. 109

\footnotetext{
${ }^{1}$ Artikel Skripsi.

2 Mahasiswa pada Fakultas Hukum Unsrat, NIM. 17071101175

${ }^{3}$ Fakultas Hukum Unsrat, Magister Ilmu Humaniora

${ }^{4}$ Fakultas Hukum Unsrat, Magister Ilmu Hukum
}

Tahun 2012 tentang Pengamanan Bahan Yang Mengandung Zat Adktif Berupa Produk Tembakau Bagi Kesehatan. Penerapan kebijakan hukum tentang kawasan tanpa rokok di Kota Manado didapati adanya kekosongan hukum, dalam hal ini tidak adanya Peraturan Walikota mengenai pembentukan Satuan Tugas Penegak Kawasan Tanpa Rokok guna menerapkan peraturan daerah tersebut. Kata kunci : rokok; kawasan tanpa rokok; Kota Manado;

\section{PENDAHULUAN}

\section{A. Latar Belakang}

Perlunya payung hukum terkait kawasan tanpa rokok menjadi kewajiban hukum bagi negara dalam hal ini, pemerintah pusat dan pemerintah daerah untuk memberikan perlindungan hukum kepada masyarakat dan orang perorangan akan bahaya dari paparan asap rokok pada kesehatan serta pemenuhan atas hak asasi setiap orang atas lingkungan yang bersih, sehat dan bebas dari paparan asap rokok. Hal ini merupakan upaya yang harus dilakukan oleh pemerintah daerah beserta masyarakat yang terkait agar Kota Manado dapat bebas dari asap rokok, terutama pada tempat - tempat yang telah ditetapkan dalam Peraturan Daerah Kota Manado Nomor 5 Tahun 2017 tentang Kawasan Tanpa Rokok.

\section{B. Rumusan Masalah}

1. Bagaimana pengaturan hukum terhadap kawasan tanpa rokok menurut peraturan perundang undangan ?

2. Bagaimana penerapan kebijakan hukum tentang kawasan tanpa rokok di Kota Manado ?

\section{Metode Penelitian}

Jenis penelitian yang digunakan oleh penulis adalah penelitian yuridis normatif, yaitu dengan melakukan pendekatan kepada peraturan perundang - undangan dan konsep - konsep.

\section{PEMBAHASAN}

A. Pengaturan Hukum Terhadap Kawasan Tanpa Rokok Menurut Peraturan Perundang Undangan 
Kesehatan merupakan hak asasi manusia yang dipengaruhi oleh berbagai faktor salah satunya adalah lingkungan yang sehat. Terkait masalah yang ditimbulkan rokok, kegiatan mengkonsumsi rokok dapat mengganggu kesehatan karena kegiatan merokok akan menimbulkan asap rokok yang akan mencemari udara dan menyebabkan berbagai macam penyakit.

Faktanya bahwa merokok dapat merugikan dan membahayakan kesehatan dikarenakan rokok merupakan produk tembakau yang mengandung zat adiktif, sebagaimana telah diatur pada Pasal 113 ayat (2) Undang - Undang No. 36 tahun 2009 tentang Kesehatan dan Pasal 1 butir 1 dan Pasal 4 Peraturan Pemerintah Nomor 109 Tahun 2012 tentang Pengamanan Bahan Yang Mengandung Zat Adiktif Berupa Produk Tembakau Bagi Kesehatan. Dalam rangka memenuhi kebutuhan asasi masyarakat atas perlindungan hak atas lingkungan yang sehat dan bersih dari paparan asap rokok, pada Pasal 115 ayat (1) Undang - Undang No. 36 tentang Kesehatan, menyatakan tempat - tempat yang termasuk ke dalam kawasan tanpa rokok antara lain fasilitas pelayanan kesehatan, fasilitas proses belajar mengajar, fasilitas anak bermain, tempat ibadah, angkutan umum, tempat kerja, tempat umum dan tempat lain yang ditetapkan. Pada Pasal 115 ayat (2) memberikan amanat kepada pemerintah daerah untuk wajib menetapkan kawasan tanpa rokok di wilayahnya. Hal ini merupakan bentuk perwujudan dari asas perlindungan, yang berarti bahwa pembangunan kesehatan harus dapat memberikan perlindungan dan kepastian hukum kepada pemberi dan penerima pelayanan kesehatan. Hal tersebut diatur pada Pasal 6 Undang - Undang No. 36 Tahun 2009 tentang Kesehatan. Terkait masalah yang disebabkan kegiatan mengkonsumsi rokok terhadap kesehatan lingkungan, pengaturan terhadap kawasan tanpa rokok juga di latar belakangi oleh Undang - Undang No. 32 Tahun 2009 tentang Perlindungan Dan Pengelolaan Lingkungan Hidup. Keadaan lingkungan dapat memengaruhi kondisi kesehatan masyarakat. Banyak aspek kesejahteraan manusia dipengaruhi oleh lingkungan, dari studi tentang kesehatan lingkungan tersirat informasi bahwa status kesehatan seseorang dipengaruhi oleh faktor hereditas, nutrisi, pelayanan kesehatan, perilaku dan lingkungan. 5

Untuk itulah pentingnya perlindungan dan pengelolaan lingkungan hidup dilaksanakan berdasarkan asas tanggung jawab negara yang dalam artian negara menjamin hak warga negara atas lingkungan hidup yang baik dan sehat sebagaimana diatur dalam Pasal 2 huruf a Undang - Undang No. 32 Tahun 2009 tentang Perlindungan Dan Pengelolaan Lingkungan Hidup. Pengaturan terhadap kawasan tanpa rokok juga selaras dengan tujuan Undang - Undang No. 32 Tahun 2009 tentang Perlindungan dan Pengelolaan Lingkungan Hidup yang terdapat pada Pasal 3 huruf $b$ dan g, yakni menjamin keselamatan, kesehatan, dan kehidupan manusia serta menjamin pemenuhan dan perlindungan hak atas lingkungan hidup sebagai bahan dari hak asasi manusia. Pengaturan terhadap kawasan tanpa rokok kemudian diatur dalam Peraturan Bersama Menteri Kesehatan Dan Menteri Dalam Negeri Nomor 188/MENKES/PB/I/2011 Nomor 7 Tahun 2011 tentang Pedoman Pelaksanaan Kawasan Tanpa Rokok. Dalam menindaklanjuti amanat peraturan perundang - undangan terkait upaya pengamanan bahan yang mengandung zat adiktif berupa produk tembakau bagi kesehatan dengan menetapkan kawasan tanpa rokok, pemerintah membuat Peraturan Pemerintah No. 109 Tahun 2012 tentang Pengamanan Bahan Yang Mengandung Zat Adiktif Berupa Produk Tembakau Bagi Kesehatan.

B. Penerapan Kebijakan Hukum Tentang Kawasan Tanpa Rokok Di Kota Manado

Di Kota Manado sendiri sudah didapati Peraturan Daerah Kota Manado No. 5 Tahun 2017 tentang Kawasan Tanpa Rokok. Sebagaimana menindaklanjuti Peraturan Gubernur Sulawesi Utara No. 31 Tahun 2017 tentang Kawasan Tanpa Rokok. Menurut Peraturan Daerah Kota Manado No. 5 tahun 2017 Pasal 2 ayat (2), menyatakan bahwa penyelenggaraan Kawasan Tanpa Rokok

\footnotetext{
${ }^{5}$ Sri Herlina dan Mustafa Lutfi, Kesehatan Masyarakat : Implementasi, Konsep, Skenario Kasus, Dan Dasar Hukum, Malang, Intimedia, 2019, HIm. 146.
} 
sebagaimana dimaksud pada ayat (1) bertujuan untuk:

- Melindungi kesehatan perseorangan, keluarga, masyarakat, dan lingkungan dari bahaya bahan yang mengandung karsinogen dan zat adiktif dalam produk tembakau yang dapat menyebabkan penyakit, kematian dan menurunkan kualitas hidup.

- Melindungi penduduk usia produktif, anak, remaja dan perempuan hamil dari dorongan lingkungan dan pengaruh iklan dan promosi untuk inisiasi penggunaan dan ketergantungan terhadap bahan yang mengandung zat adiktif berupa produk tembakau.

- Meningkatkan kesadaran dan kewaspadaan masyarakat terhadap bahaya merokok dan manfaat hidup tanpa rokok.

- Melindungi kesehatan masyarakat dari asap rokok orang lain.

Pasal 3 mengatur tentang ruang lingkup pengaturan Peraturan Daerah Kota Manado No. 5 Tahun 2017, meliputi tanggung jawab pemerintah daerah, penetapan kawasan tanpa rokok, kewajiban pimpinan atau penanggung jawab kawasan tanpa rokok, partisipasi masyarakat, pembinaan dan pengawasan oleh pemerintah daerah, ketentuan penyidikan, sanksi administrasi dan sanksi pidana.

Sementara itu mengenai pembinaan dan pengawasan terhadap kawasan tanpa rokok diatur Perda kota Manado No. 5 tahun 2017 pada Pasal 19 ayat (1), (2), (3), (4), (6) dan (7). Pada ayat (1) menyatakan bahwa, "Walikota berwenang melakukan pembinaan dan pengawasan pada kawasan tanpa rokok".

Pada ayat (4), "Dalam rangka pembinaan dan pengawasan sebagaimana dimaksud pada ayat (1), walikota wajib membentuk Satuan Tugas Penegak Kawasan Tanpa Rokok. Pada ayat (7), "ketentuan lebih lanjut mengenai tata cara pembinaan dan pengawasan sebagaimana dimaksud diatur lebih lanjut dengan Peraturan Walikota".

Namun semenjak Perda ini diundangkan pada 25 Oktober 2017, belum ada Peraturan Walikota sebagaimana dimaksud pada Pasal 19 ayat (7) Perda Kota Manado No. 5 Tahun 2017 untuk mengatur secara khusus tentang pembentukan Satuan Tugas Penegak Kawasan Tanpa Rokok (Pasal 19 ayat (4)). Disimpulkan bahwa Peraturan Daerah Kota Manado No. 5 tahun 2017 belum memenuhi pedoman pelaksanaan kawasan tanpa rokok.

Pada undang - undang sendiri dikatakan bahwa kewenangan penegakan Perda kawasan tanpa rokok di daerah kabupaten/kota terdapat pada Satuan Tugas Penegak Kawasan Tanpa Rokok, hal ini telah diatur melalui Perda Kota Manado No. 5 Tahun 2017 pada Pasal 1 angka 6 berbunyi : "Satuan Petugas Penegak Kawasan Tanpa Rokok adalah pegawai negeri sipil di lingkungan pemerintah daerah dan/atau individu yang ditunjuk oleh kepala daerah dan mempunyai tugas untuk membina dan mengawasi pelaksanaan kegiatan perlindungan bagi masyarakat bukan perokok", kemudian pada Pasal 22 ayat (3), (4), (5) dan (6), jelas - jelas menyatakan bahwa sanksi administrasi diberikan oleh Satuan Petugas Penegak Kawasan Tanpa Rokok.

Dapat disimpulkan bahwa kewenangan untuk menegakan dan menerapkan Perda Kawasan Tanpa Rokok terdapat pada Satuan Tugas Penegak Kawasan Tanpa Rokok, di samping Kewenangan Walikota yang telah diatur pada Pasal 19 ayat (1). Maka dapat dilihat urgensi dari pembentukan Satuan Tugas Penegak Kawasan Tanpa Rokok di Kota Manado. Hal ini menjadi persoalan hukum dalam penerapan kebijakan hukum tentang kawasan tanpa rokok di Kota Manado.

Berdasarkan uraian di atas, maka didapati adanya kekosongan hukum dalam penerapan kebijakan hukum tentang kawasan tanpa rokok di Kota Manado melalui Peraturan Daerah Kota Manado No. 5 Tahun 2017 tentang Kawasan Tanpa Rokok. Tidak adanya Peraturan Walikota Kota Manado yang secara khusus mengatur mengenai pembentukan alat pelaksana hukum yang dimaksud adalah Satuan Tugas Penegak Kawasan Tanpa Rokok sehingga menyebabkan norma hukum atas kawasan tanpa rokok menjadi terbengkalai.

Sampai saat ini, tidak ada pengertian baku mengenai kekosongan hukum. Kekosongan atau vacuum, menurut Kamus Besar Bahasa Indonesia, "kekosongan adalah perihal (keadaan, sifat dan sebagainya) kosong atau kehampaan", yang dalam kamus hukum diartikan dengan vacum yang diterjemahkan 
atau diartikan sama dengan "kosong atau lowong". 6

Menurut Kamus Hukum, recht (Bld) secara objektif berarti udang - undang atau hukum. Grotius dalam bukunya "De Jure Belli ac Paris (1625)" menyatakan bahwa, "hukum adalah peraturan tentang perbuatan moral yang menjamin keadilan". Surono Wignjodipuro, S.H dalam "Pengantar IImu Hukum" memberikan pengertian mengenai hukum, yaitu, "Hukum adalah himpunan peraturan - peraturan hidup yang bersifat memaksa, berisikan suatu perintah, larangan atau izin untuk berbuat atau tidak berbuat sesuatu serta dengan maksud untuk mengatur tata tertib dalam kehidupan masyarakat". ${ }^{7}$

Dari penjelasan diatas, maka secara sempit kekosongan hukum dapat diartikan sebagai suatu keadaan kosong atau ketiadaan peraturan perundang - undangan atau hukum yang mengatur tata tertib tertentu dalam masyarakat sehingga kekosongan hukum dalam hukum positif lebih tepat dikatakan sebagai kekosongan undang - undang atau peraturan perundang - undangan.

Akibat yang ditimbulkan karena adanya kekosongan hukum, terhadap hal - hal atau keadaan yang tidak atau belum diatur itu dapat terjadi ketidakpastian hukum (rechtsonzekerheid) atau ketidakpastian peraturan perundang - undangan di masyarakat yang lebih jauh lagi akan berakibat pada kekacauan hukum (rechtswarring), dalam arti bahwa selama tidak diatur berarti boleh, selama belum belum ada tata cara yang jelas dan diatur berarti bukan tidak boleh. ${ }^{8}$

Penerapan kebijakan hukum tentang kawasan tanpa rokok di Kota Manado belum dapat memberikan perlindungan dan kepastian hukum atas hak akan lingkungan hidup yang bersih, sehat dan bebas dari paparan asap rokok yang membahayakan kesehatan.

Penerapan kebijakan hukum tentang kawasan tanpa rokok di Kota Manado juga

\footnotetext{
6 Tiar Ramon, “Kekosongan Hukum", ARTIKEL, 13 Desember 2009, Di Akses Dari, https://tiarramon.wordpress.com/2009/12/13/dile ma-hukuman-mati/, Pada Tanggal 19 September 2020, Pukul 00.35 WITA.

${ }^{7} \mathrm{lbid}$.

${ }^{8}$ Ibid.
}

belum memenuhi asas tanggung jawab negara dalam menjamin hak warga negara atas lingkungan hidup yang baik dan sehat sebagaimana tertuang pada penjelasan asas tanggung jawab negara dalam perlindungan dan pengelolaan lingkungan hidup.

Ridwan H. R dalam Buku Hukum Administrasi Negara (hlm. 101 - 102) menjelaskan bahwa seiring dengan pilar utama negara hukum, yaitu asas legalitas, maka berdasarkan prinsip ini tersirat bahwa wewenang pemerintahan berasal dari peraturan perundang - undangan, artinya sumber wewenang bagi pemerintah adalah peraturan perundang - undangan. ${ }^{9}$

Pentingnya Walikota Manado membentuk Satuan Tugas Penegak Kawasan Tanpa Rokok melalui Peraturan Walikota karena jika ditinjau dari konsep negara hukum, setiap tindakan yang dilakukan negara harus berdasarkan hukum atau peraturan perundang - undangan yang telah diadakan terlebih dahulu (asas legalitas). Begitu juga penegakan terhadap Peraturan Daerah Kota Manado No. 5 Tahun 2017 tentang Kawasan Tanpa Rokok.

\section{PENUTUP}

\section{A. Kesimpulan}

1. Mengingat kembali permasalahan yang ditimbulkan oleh bahaya rokok bagi kesehatan sebagaimana telah diatur pada Pasal 113 ayat (1) dan (2) Undang - Undang No. 36 Tahun 2009 dan Pasal 4 Peraturan Pemerintah No. 109 Tahun 2012 tentang Pengamanan Bahan Yang Mengandung Zat Adktif Berupa Produk Tembakau Bagi Kesehatan, maka perlunya pengaturan hukum terkait pengamanan bahan yang mengandung zat adiktif berupa produk tembakau bagi kesehatan melalui penetapan kawasan tanpa rokok. Pengaturan terhadap kawasan tanpa rokok dapat didapati pada Pasal 115 Undang - Undang No. 36 Tahun 2009 tentang Kesehatan. Pengaturan

\footnotetext{
${ }^{9}$ Sovia Hasanah, 2016, Pengertian Atribusi, Delegasi Dan Mandat, Di Akses Dari, https://www.hukumonline.com/klinik/detail/ulasa n/lt5816ab6ea74a7/pengertian-atribusi--delegasidan-mandat/, Pada Tanggal 23 September 2020, Pukul 14.03 WITA.
} 
terhadap kawasan tanpa rokok juga terdapat dalam Peraturan Bersama Menteri Kesehatan dan Menteri Dalam Negeri Nomor 188/MENKES/PB/I/2011 Nomor 7 Tahun 2011 tentang Pedoman Pelaksanaan Kawasan Tanpa Rokok, serta Peraturan Pemerintah No. 109 Tahun 2012 tentang Pengamanan Bahan Yang Mengandung Zat Adktif Berupa Produk Tembakau Bagi Kesehatan.

2. Penerapan kebijakan hukum tentang Kawasan Tanpa Rokok di Provinsi Sulawesi Utara, terlebih khusus di Kota Manado telah diatur melalui Peraturan Daerah Kota Manado Nomor 5 Tahun 2017 tentang Kawasan Tanpa Rokok, namun penerapan kebijakan hukum tentang kawasan tanpa rokok di Kota Manado didapati adanya kekosongan hukum, dalam hal ini tidak adanya Peraturan Walikota mengenai pembentukan Satuan Tugas Penegak Kawasan Tanpa Rokok guna menerapkan Perda tersebut. Perda Kota Manado No. 5 Tahun 2017 Pasal 19 ayat (4) dan (7) telah memberikan kewajiban kepada Walikota untuk membuat Peraturan Walikota tentang pembentukan Satuan Tugas Penegak Kawasan tanpa Rokok. Pasalnya, pada Peraturan Bersama Menteri Kesehatan dan Menteri Dalam Negeri Nomor 188/MENKES/PB/I/2011 Nomor 7 Tahun 2011 tentang Pedoman Pelaksanaan Kawasan Tanpa Rokok Pasal 6 ayat (2) telah menyatakan bahwa, "Peraturan daerah sebagaimana dimaksud pada ayat (1) paling sedikit memuat pengaturan tentang kawasan tanpa rokok, peran serta masyarakat, pembentukan satuan tugas penegak kawasan tanpa rokok, larangan dan kewajiban dan sanksi". Namun semenjak Perda tentang KTR di Kota Manado ini diundangkan, belum ada Peraturan Walikota Manado yang mengatur tentang pembentukan Satuan Tugas Penegak Kawasan Tanpa Rokok. Berdasarkan uraian di atas didapati penerapan kebijakan hukum tentang kawasan tanpa rokok di Kota Manado belum memenuhi Pasal 113 Undang Undang No. 36 Tahun 2009 tentang Kesehatan, Pasal 2 huruf a dan Pasal 3 huruf $b$ dan g Undang - Undang No. 32 Tahun 2009 tentang Perlindungan dan Pengelolaan Lingkungan Hidup, Pasal 49 dan Pasal 57 Peraturan Pemerintah No. 109 Tahun 2012 tentang Pengamanan Bahan Yang Mengandung Zat Adiktif Berupa Produk Tembakau Bagi Kesehatan dan Pasal 6 ayat (2) Peraturan Bersama Menteri Kesehatan dan Menteri Dalam Negeri No. 188/MENKES/PB/I/2011 No. 7 Tahun 2011 tentang Pedoman Pelaksanaan Kawasan Tanpa Rokok.

\section{B. Saran}

1. Sudah seharusnya negara dalam hal ini pemerintah dan pemerintah daerah memberikan perlindungan hukum kepada masyarakat dan individu dari bahaya paparan asap rokok bagi kesehatan serta melindungi hak asasi manusia atas lingkungan hidup yang bersih, sehat dan bebas dari paparan asap rokok dengan membuat pengaturan hukum terhadap kawasan tanpa rokok sesuai amanat dari Undang - Undang Dasar Negara Republik Indonesia Tahun 1945 Pasal $28 \mathrm{H}$, Undang - Undang Kesehatan No. 36 Tahun 2009 tentang Kesehatan Pasal 113 dan 115 , Undang - Undang No. 32 Tahun 2009 tentang Perlindungan dan Pengelolaan Lingkungan Hidup Pasal 3 huruf $b$ dan g serta Peraturan Pemerintah No. 109 Tahun 2012 tentang Pengamanan Bahan Yang Mengandung Zat Adiktif Berupa Produk Tembakau Bagi Kesahatan pada Pasal 49.

2. Seharusnya Walikota Manado membentuk Satuan Tugas Penegak Kawasan Tanpa Rokok melalui Peraturan Walikota seperti yang sudah diamanatkan dalam Pasal 19 ayat (4) angka 1 dan ayat (7) Peraturan Daerah Kota Manado Nomor 5 Tahun 2017 tentang Kawasan Tanpa Rokok dan Peraturan Bersama Menteri Kesehatan dan Menteri Dalam Negeri No. 
188/MENKES/PB/I/2011 No. 7 Tahun 2011 tentang Pedoman Pelaksanaan Kawasan Tanpa Rokok Pasal 6 ayat (2), agar terciptanya kepastian hukum dan terpenuhinya asas legalitas dalam rangka pemenuhan hak asasi atas lingkungan hidup yang sehat, bersih dan bebas dari paparan asap rokok. Walikota Manado juga harus menyediakan Kawasan Khusus Merokok agar perokok dapat melakukan aktivitasnya tanpa melanggar hak orang lain.

\section{DAFTAR PUSTAKA}

\section{Literatur}

Arliman Laurensius S., Penegakan Hukum Dan Kesadaran Masyarakat, Deepublish, 2015.

Komentar Umum Kovenan Internasional : Hak Sipil Dan Politik, Hak Ekonomi Sosial Dan Budaya, Komisi Nasional Hak Asasi Manusia, Jakarta, 2009.

Marindrawati Mega, Anwar A. Awaliya dan Rahmadani Suci, Kawasan Tanpa Rokok Di Fasilitas Umum, Uwais Inspirasi Indonesia, Jawa Timur, 2019.

Raharjo Handri, Sistem Hukum Indonesia Ketentuan - Ketentuan Hukum Indonesia Dan Hubungannya Dengan Hukum Internasional, Media Pressindo, Yogyakarta.

Sri Herlina dan Mustafa Lutfi, Kesehatan Masyarakat : Implementasi, Konsep, Skenario Kasus, Dan Dasar Hukum, Intimedia, Malang, 2019.

Suteki dan Taufani Galang, Metodologi Penelitian Hukum (Filsafat, Teori dan Praktik), PT Raja Grafindo, Depok, 2018.

Sukmana Teddie, Mengenal Rokok Dan Bahayanya, Be Champion. Jakarta, 2011.

\section{Jurnal}

Achmad Irwan Hamzani, "Menggagas Indonesia Sebagai Negara Hukum Yang Membahagiakan Rakyatnya". Yustisio Edisi 90, September Desember 2014.

Andrian Liem, "Pengaruh Nikotin Terhadap Aktivitas Dan Fungsi Otak Serta
Hubungannya Dengan Gangguan Psikologis Pada Pecandu Rokok". Buletin Psikologi, Vol. 18, No. 2, 2010.

Asmaunizar, 2018, "Pengaruh Iklan Bahaya Merokok Terhadap Tingkat Konsumsi Rokok Pada Masyarakat Pekerja Keras/Tukang Bangunan Di Gampong Keutupang Lhoksukon Aceh Utara". Al - Idarah, Vol. 2, No. 2, Juli - Desember 2018.

Isriawaty Fheriyal Sri, "Tanggung Jawab Negara Dalam Pemenuhan Hak Atas Kesehatan Masyarakat Berdasarkan Undang - Undang Dasar Negara Republik Indonesia Tahun 1945". Jurnal IImu Hukum Legal Opinion, Edisi 2, Vol. 3, 2015, HIm. 3.

I Gusti Agung Ngurah Iriandhika Prabhata, "Meningkatkan Pariwisata Bali Melalui Kepastian Penegakan Hukum Atas Pelanggaran Kawasan Tanpa Rokok Dalam Peraturan Daerah Propinsi Bali Nomor 10 Tahun 2011". Udayana Master Law Journal, Vol. 4, No. 1 : 57 68, Mei 2015.

Jeffry Alexander Ch. Likadja, "Memaknai "Hukum Negara (Law Through State)" Dalam Bingkai negara hukum (Rechtstaat)". Hasanudin Law Review, Vol. 1, No. 1, April 2015.

Kwe Fei Lie Shirley Dkk, "Kebijakan Tentang Pedoman Kawasan Tanpa Rokok Dikaitkan Dengan Asas Manfaat". SOEPRA Jurnal Hukum Kesehatan, Vol. 2, No. 1, 2016.

Nurjanah dkk, "Gangguan Fungsi Paru Dan Kadar Cotinine Pada Urin Karyawan Yang Terpapar Asap Rokok Orang Lain". Jurnal Kesehatan Masyarakat, Vol. 10, No. 1, 2014.

\section{Perundang - Undangan}

- Undang - Undang Dasar Negara Republik Indonesia Tahun 1945 Pasal 1 ayat (3) dan Pasal $28 \mathrm{H}$ ayat (1).

- Undang - Undang Nomor 39 Tahun 1999 tentang Hak Asasi Manusia.

- Undang - Undang Nomor 11 Tahun 2005 tentang Pengesahan International Covenant On Economic, Social And Cultural Right (Kovenan 
Internasional Tentang Hak - Hak Ekonomi, Sosial Dan Budaya)

- Undang - Undang Nomor 36 Tahun 2009 tentang Kesehatan.

- Undang - Undang Nomor 32 Tahun 2009 tentang Perlindungan dan Pengelolaan Lingkungan Hidup.

- Peraturan Bersama Menteri Kesehatan dan Menteri Dalam Negeri Nomor 188/MENKES/PB/I/2011 Nomor 7 Tahun 2011 tentang Pedoman Pelaksanaan Kawasan Tanpa Rokok.

- Peraturan Pemerintah Republik Indonesia Nomor 109 Tahun 2012 tentang Pengamanan Bahan Yang Mengandung Zat Adiktif Berupa Produk Tembakau Bagi Kesehatan .

- Peraturan Gubernur Sulawesi Utara Nomor 31 Tahun 2017 tentang Kawasan Tanpa Rokok.

- Peraturan Daerah Kota Manado Nomor 5 Tahun 2017 tentang Kawasan Tanpa Rokok.

- Peraturan Daerah Kabupaten Kebumen Nomor 10 Tahun 2017 tentang Kawasan Tanpa Rokok.

- Peraturan Bupati Kebumen Nomor 66 Tahun 2017 tentang Petunjuk Pelaksanaan Peraturan Daerah Kabupaten Kebumen Nomor 10 Tahun 2017 tentang Kawasan Tanpa Rokok.

\section{Website}

Rafika Dewi Diah, "Rokok Dan Dampak Negatifnya", Kompasiana, 14 Agustus 2013, Di akses Dari, https://www.kompasiana.com/diahraf ikadewi/552b0cb56ea8341e1e552cfa/ rokok-dan-dampak-negatifnya, Pada Tanggal 9 September 2020.

Sovia Hasanah, 2016, Pengertian Atribusi, Delegasi Dan Mandat, Di Akses Dari, https://www.hukumonline.com/klinik/ detail/ulasan/It5816ab6ea74a7/penge rtian-atribusi--delegasi-dan-mandat/, Pada Tanggal 23 September 2020.

Tiar Ramon, "Kekosongan Hukum", ARTIKEL, 13 Desember 2009, Di Akses Dari, https://tiarramon.wordpress.com/200 9/12/13/dilema-hukuman-mati/, Pada Tanggal 19 September 2020.
WHO, Pernyataan : Hari Tanpa Tembakau Sedunia 2020, 30 Mei 2020, Di akses Dari,

https://www.who.int/indonesia/news/ detail/30-05-2020-pernyataan-haritanpa-tembakau-sedunia-2020, Pada Tanggal 28 Agustus 2020. 